\title{
Determination of Operating Characteristics of 540 and 540E PTO Applications in Disc Type Silage Machines
}

\author{
Osman Özbek ${ }^{1, a, *}$, Mustafa Ahmed Jalal Al-Sammarraie ${ }^{2, b}$ \\ ${ }^{I}$ Department of Agricultural Machineries and Technologies Engineering, Faculty of Agriculture, Selçuk University, 42250 Konya, Turkey \\ ${ }^{2}$ Department of Agricultural Machinery and Equipment, College of Agricultural Engineering Sciences, University of Baghdad, Baghdad, Iraq \\ *Corresponding author

A R T I C L E IN F O A B S T R A C T \\ Research Article \\ In this study, performance characteristics such as power take off (PTO) power consumption, fuel \\ consumption, fuel consumption for the unit field-unit product were determined at different working \\ speeds with two different PTO applications (540 and 540E) in a single row disc type silage machine. \\ In particular, the 540E PTO application greatly reduces fuel consumption for unit work. The best \\ Received : 25/03/2020 \\ Accepted : 26/05/2020 \\ results in terms of hourly fuel consumption were achieved in 540E PTO application and $\mathrm{V}_{1}$ working \\ speed. When the field - product fuel consumption is evaluated, the best results were obtained with \\ the 540E PTO application at the $\mathrm{V}_{3}$ working speed. When an evaluation is made considering all the \\ parameters, it is concluded that the 540E PTO application will provide certain advantages in terms \\ of fuel consumption compared to the 540 PTO application for the silage machine operating by \\ taking the motion from PTO. 540E PTO application can be used as an important alternative to 540 \\ Keywords: \\ PTO application for machines of similar capacity and features. \\ Economical PTO
}

Fuel consumption

Power take off

Silage machine

Field- product working capacity

ozbek@selcuk.edu.tr

iD http://orcid.org/0000-0003-0034-9387 |b@ mustafa.ahm@coagri.uobaghdad.edu.iq

iD https://orcid.org/0000-0003-3265-2989

(c) (1) (9) This work is licensed under Creative Commons Attribution 4.0 International License

\section{Introduction}

The term mechanization in agriculture (agricultural mechanization) means that agricultural processes are carried out using machinery and energy. In this way, faster and larger capacity production is possible. Unlike other agricultural technology applications, the use of machinery in agriculture does not directly affect the increase in yield; but it ensures the application of new production methods. In this respect, it increases the efficiency and economy of other technological applications and also improves the working conditions. Thus, it helps to obtain more efficiency from certain sized production areas by enabling the use of appropriate technologies (Saral and Avcıoglu, 2002).

The power generated in the tractor engine is known as drive, hydraulic and PTO power. The power obtained must be sufficient to meet the needs of agricultural equipment and machinery used with the tractor. Otherwise, more energy will be required to complete the process. The tractor will need to consume more fuel to meet this energy. Priority is given to the realization of agricultural activities by a tractor with a wide working range and low fuel consumption (Çiftçi and Çalışır, 2018).

The power required to move the tractor, trailer and silage machine can be calculated from known methods. In disk type silage machines, $83-88 \%$ of the required power is consumed for the chopping of the material, 5-8\% is used for the operation of the collector, auger and precompression rollers, 5-6.5\% in the upper feed rollers, 2$3.5 \%$ is consumed in the lower feed rollers (Güner, 1998).

Disc type machines are generally used in maize silage. Single rows of these machines (for effective capacities) require tractor power of 40-80 HP, two rows of 80-120 HP and four rows of $120 \mathrm{HP}$ (Evrenosoğlu, 2006). After the green bait is chopped, it must be thrown or transmitted to the trailer behind. In order to realize this transmission, the speed of the silage is increased to the drum or disk speed, that is, the silage is accelerated. Additional power is needed for this increase (Güner, 1998). 
It is for the PTO speeds to be met in a region very close to the maximum speed of the engine, for the loads to be met by the machine in the best way. However, operating the engine at high speeds in some agricultural machines with very low power requirements causes unnecessary energy, and consequently high fuel consumption and an uneconomical application. Tractor manufacturers are working on power output points that reduce fuel consumption when working with PTO at appropriate engine speed, at standard PTO speeds (Anonymous, 2008).

As well as knowing the tractor's working efficiency, the torque, speed and power requirement of the machine being operated are also important. In the event that these features are known, tractors in the power class, where the related machine can be used efficiently, can also be determined. Taking into consideration the negativities such as fuel consumption, unnecessary power usage, transmission manufacturers have been developed by tractor manufacturers to provide 540E PTO speed versus $540 \mathrm{~min}^{-}$ ${ }^{1}$ standard PTO speed value and 1000E PTO speed for 1,000 $\mathrm{min}^{-1}$ standard PTO speed at lower speeds of the engine or $750 \mathrm{~min}^{-1}$ standard PTO speed for operating machines with less torque requirement.

The unit, which provides 540 and 540E PTO applications, transfers the engine speed to the PTO with two different transmission rates. In this way, the PTO speed $\left(540 \mathrm{~min}^{-1}-540 \mathrm{E}\right.$ or $\left.1,000 \mathrm{~min}^{-1}-1000 \mathrm{E}\right)$, which is standard with a higher transmission rate and lower engine speed, can be provided. The change between the two ratios can be done mechanically or electro-hydraulically (Sümer et al., 2004; Sümer et al. 2010a).

This study was carried out to determine the performance characteristics, such as PTO power consumption, fuel consumption, fuel consumption for unit field-unit product were determined at different working speeds with two different PTO applications (540 and 540E) in a single row disc type silage machine.

\section{Materials and Methods}

In the study, the first product silage corn plant (Zea mays indentata) was harvested with a single row disc type silage machine. Some features of a silage corn plant, which is trial material, are given in Table 1.

The trials were conducted in 2018 at the Research and Application Centre of the Faculty of Agriculture, Selcuk University. The experiments were arranged according to randomized plots and they were designed with three replications.

Trials were carried out on two different PTO applications (540 and 540E) of the tractor and three different feed speeds $\mathrm{V}_{1}, \mathrm{~V}_{2}$ and $\mathrm{V}_{3}\left(1.8,2.5\right.$ and $\left.3.7 \mathrm{~km} \mathrm{~h}^{-1}\right)$.

For this purpose, within the Agricultural Machinery and Technologies Engineering Department of the Faculty of Agriculture; New Holland TD110D tractor equipped with fuel meter, PTO torque meter and speed sensors is used. On the tractor, the PTO speed numbers corresponding to the engine speed and which engine speeds correspond are shown. According to this demonstration, the $540 \mathrm{~min}^{-1}$ speed for 540 and 540E PTO applications is achieved at 2,200 and 1,600 $\mathrm{min}^{-1}$ engine speeds, respectively. The same speeds were obtained at different gear levels for the application of two different drive shafts.
Some technical features of the silage machine used in the study are shown in Table 2 . The trial-type machine is a hanging type, single-row disc maize silage machine. The machine takes its movement from the PTO.

The silage material is to be cut with the cutting disc knives on the two feeders of the machine. The extruded material is compressed between the feeding drums and transferred to the mincing knives. The chopper knives are 12 pieces and are attached to a disc which is located in the hood. Chopper unit is a radial knife type and consists of a knife and counter knife. The conveying of the mater-years to the trailer with the transmission pipe by means of the airflow generated by the chopper knives and launching wings. There are sharpening stones on the body of the hood to sharpen the curved bi-pebbles. The material transmission pipe is controlled by the hydraulic cylinder driven by the hydraulic pump on the machine.

Datum brand Series 420 PTO $1800 \mathrm{Nm}$ model torque meter was used to measure the torque and torque of the tractor. The data received from the torque meter connected to the spindle is transferred to the computer via the data logging system.

In the study, fuel was measured by PLC (Programmable Logic Controller) software of a mechanical type liquid flow sensor of Sea YF-S401 to measure the fuel consumption in the combinations.

In order to determine the starting and ending points during the experiments, a tape meter was used. During the harvest, the plant moisture was dried in an oven. Also measuring calipers, precision scales, time measurements 0.1 seconds precision stopwatch, etc. Ancillary tools were used.

Table 1. Some physical properties of a silage corn plant

\begin{tabular}{l|r}
\multicolumn{1}{c|}{ Property } & \multicolumn{1}{c}{ Value } \\
\hline Average Stubble Height $(\mathrm{mm})$ & 183.07 \\
Average plant height $(\mathrm{mm})$ & 2,553 \\
Average Plant Weight $(\mathrm{g})$ & 872.46 \\
Row spacing $(\mathrm{mm})$ & 700 \\
Plant diameter $(\mathrm{mm})$ & 27.6 \\
Field yield $\left(\mathrm{kg} \mathrm{ha}^{-1}\right)$ & 44,937 \\
Plant moisture level $(\%)(\mathrm{wb})$ & 70.56 \\
\hline
\end{tabular}

Table 2. Technical information of the silage machine

\begin{tabular}{l|l}
\hline \multicolumn{1}{c|}{ Structural Properties } & \multicolumn{1}{c}{ Values } \\
\hline Total length $(\mathrm{mm})$ & max.3,900, min.2,800 \\
Total width $(\mathrm{mm})$ & 2,420 \\
Total height $(\mathrm{mm})$ & max.3,445, min.3,240 \\
Weight $(\mathrm{kg})$ & 660 \\
Control device & Hydraulic \\
PTO speed & 540 min $^{-1}$ \\
Drive & transmission \\
Number of Drum (pcs) & 2 \\
Number of the bottom cutter (pcs) & 2 \\
Number of knives & 12 \\
Number of Blowing Wings & 6 \\
\hline
\end{tabular}

In this study; plant height, moisture content, stubble height, plant weight, green product yield (field yield), unit field of the silage machine and product business success, PTO force, working speed, unit field, and product energy consumption, fuel consumption, and material chopping length were measured. Then, these values were averaged. 
Plant samples were taken from the stubble neck determined in experiments in different parts of the field and their dry matter contents and moisture contents were determined in the laboratory. Arin (1982) used the method of determining the moist yield of the field. The moisture content was determined on a wet basis at $105^{\circ} \mathrm{C}$ for 48 hours. PTO speed power consumptions of silage machines were determined by benefitting from rotation moment and cycle number. Field and product fuel consumptions were determined with the help of maximum PTO speed power consumption, field and product working capacities. The field working capacity of silage machines (Sf, ha $\mathrm{h}^{-1}$ ) was calculated from the following correlation with the help of the actual working speed $\left(\mathrm{V}, \mathrm{km} \mathrm{h}^{-1}\right)$, work width $(\mathrm{B}, \mathrm{m})$ and time utilization coefficient $(\mathrm{K})$.

$$
\mathrm{Sf}=0.1 . \mathrm{B} \cdot \mathrm{V} \cdot \mathrm{K}
$$

The coefficient of time-utilization coefficient of 0.500.75 recommended by ASAE (American Society of Association Executives) was $\mathrm{K}=0.70$

The product working capacity $\left(\mathrm{Sp}, \mathrm{kg} \mathrm{h}^{-1}\right)$; field yield $\left(\mathrm{S}, \mathrm{kg} \mathrm{ha} \mathrm{ha}^{-1}\right.$ ), field working capacity $\left(\mathrm{Sf}\right.$, ha $\mathrm{h}^{-1}$ ) was determined by multiplying.

$$
\mathrm{Sp}=\mathrm{Sf} . \mathrm{S}
$$

The fuel consumption was measured continuously with $\mathrm{L} \mathrm{h}^{-1}$ with the fuel gauge connected to the tractor fuel equipment and recorded under PLC control. After each trial combination, the silage samples were taken and the samples were then measured with the help of 0.01 digital caliper. The PTO power consumption of the silage machines is determined by using the torque and the number of revolutions.

Field and product fuel consumption; calculated by dividing hourly fuel consumption by field and product business successes.

Statistical analyses were performed on the data obtained from all applications. LSD test was applied to the significant averages via the MSTAT-C package program. (Düzgüneş et al., 1987; Anonymous, 1991).

\section{Results and Discussion}

Due to the fact that the PTO speed was kept constant at $540 \mathrm{~min}^{-1}$ in both PTO applications in the trials, the power requirement of the machine's shaft was also changed at similar rates (Figure 1).

As can be seen in Figure 1, the highest PTO power consumption was achieved with $9.90 \mathrm{~kW} \mathrm{~V}_{3}$ working speed, while the lowest PTO power consumption was achieved with $8.87 \mathrm{~kW} \mathrm{~V}$. working speed. PTO power consumption increases as the machine's working speed increases. An increase of $100 \%$ in the working speed increased the average PTO power consumption by $11.6 \%$. Similarly, Bilgen and Sungur (1992) state that increasing working speed increases the power consumption. Also, depending on the amount of material increasing with the speed of progress, power consumption increases (Kafadar, 1997).

The average hourly fuel consumption values obtained for both power take-offs in the trials are given in Figure 2. According to the results of variance analysis applied to the fuel consumption values obtained from the trial combinations, the effect of the change in pace on the fuel consumption was found statistically significant $(\mathrm{P}<0.05)$ and the LSD test results are given in Table 3.

When Figure 2 and Table 3 are analyzed, it is seen that the hourly fuel consumption values change in parallel with the increase and decrease in the power consumption of the PTO. The average hourly fuel consumption is $6.89 \mathrm{l} \mathrm{h}^{-1}$ at 540 PTO application and $6.071 \mathrm{~h}^{-1}$ at 540E. The lowest fuel consumption was achieved with the $\mathrm{V}_{1}$ feed rate in the $540 \mathrm{E}$ application at $5.42 \mathrm{1} \mathrm{h}^{-1}$. While the lowest average hourly fuel consumption value depending on the working speed of the machine was determined at the speed of $\mathrm{V}_{1}$, this value was followed by the speeds of $V_{2}$ and $V_{3}$ respectively. It was observed that the average hourly fuel consumption in the 540E PTO application decreased by $11.9 \%$ compared to the 540 application. An increase of $100 \%$ in the working speed increased the average fuel consumption by $37.47 \%$.

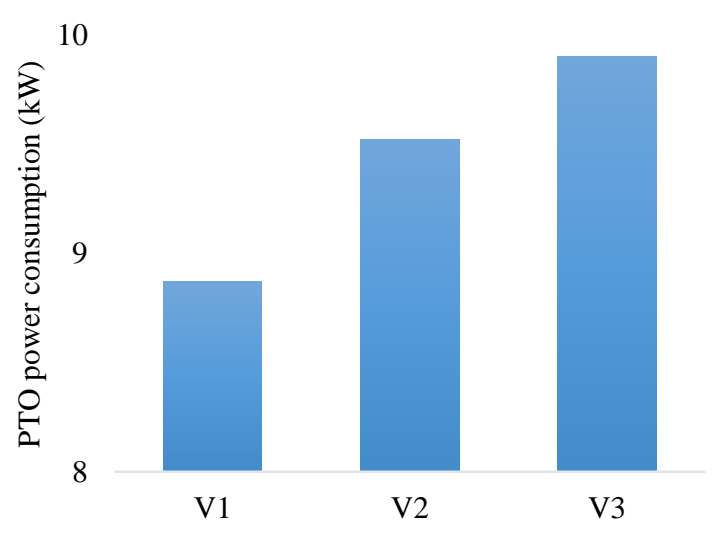

Figure 1. PTO power consumption change depending on machine working speed

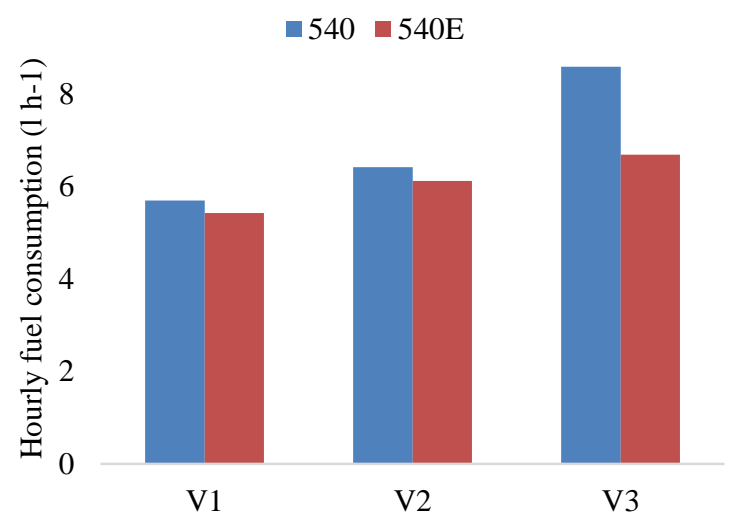

Figure 2. Hourly fuel consumption values for trial combinations

Table 3. Hourly fuel consumption values LSD test results

\begin{tabular}{l|cccc}
\hline \multirow{2}{*}{540} & \multicolumn{4}{|c}{ Hourly fuel consumption $\left(\mathrm{l} \mathrm{h}^{-1}\right)$} \\
\cline { 2 - 5 } $540 \mathrm{E}$ & $\mathrm{V}_{1}$ & $\mathrm{~V}_{2}$ & $\mathrm{~V}_{3}$ & Average \\
\hline & 5.69 & 6.41 & 8.58 & 6.89 \\
& 5.42 & 6.12 & 6.68 & 6.07 \\
\hline \multirow{2}{*}{ Average } & $5.553^{\mathrm{b}}$ & $6.262^{\mathrm{b}}$ & $7.628^{\mathrm{a}}$ & LSD $=0.82$ \\
\hline & \multicolumn{5}{|c}{ LSD $=1$} \\
\hline
\end{tabular}




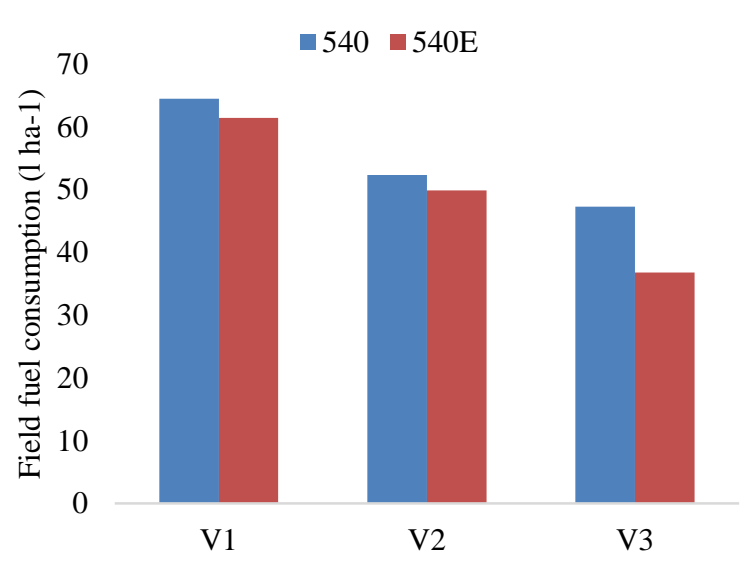

Figure 3. Field fuel consumption values for trial combinations

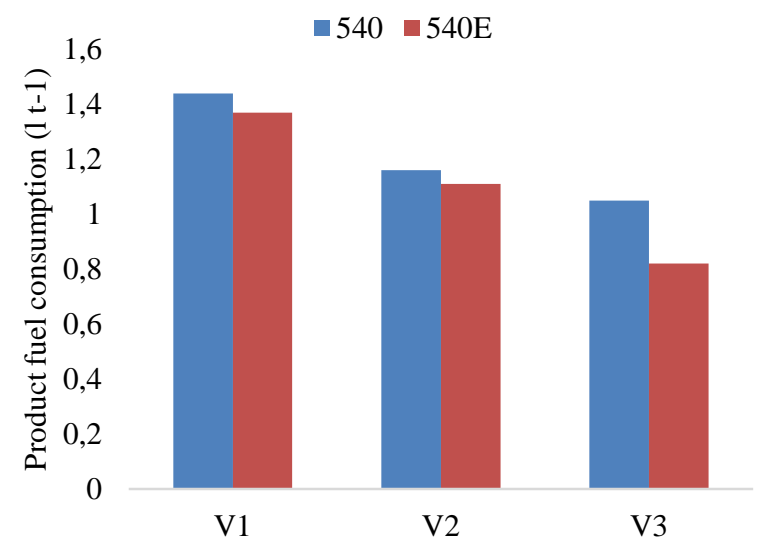

Figure 4. Product fuel consumption values for working combinations

Table 4. Field fuel consumption values LSD test results

\begin{tabular}{l|cccc}
\hline \multicolumn{5}{c}{ Field fuel consumption $\left(1 \mathrm{ha}^{-1}\right)$} \\
\hline 540 & $\mathrm{~V}_{1}$ & $\mathrm{~V}_{2}$ & $\mathrm{~V}_{3}$ & Average \\
\hline $540 \mathrm{E}$ & 64.5 & 52.3 & 47.3 & 54.7 \\
& 61.4 & 49.9 & 36.8 & 49.4 \\
\hline \multirow{5}{*}{ Average } & $62.9^{\mathrm{a}}$ & $51.1^{\mathrm{b}}$ & $42.1^{\mathrm{c}}$ & LSD = 6 \\
\hline \multicolumn{5}{c}{ LSD $=7.4$} \\
\hline
\end{tabular}

Table 5. Product fuel consumption values LSD test results

\begin{tabular}{|c|c|c|c|c|}
\hline \multicolumn{5}{|c|}{ Product fuel consumption $\left(1 \mathrm{t}^{-1}\right)$} \\
\hline & $\mathrm{V}_{1}$ & $\mathrm{~V}_{2}$ & $\mathrm{~V}_{3}$ & Average \\
\hline 540 & 1.44 & 1.16 & 1.05 & 1.22 \\
\hline $540 \mathrm{E}$ & 1.37 & 1.11 & 0.82 & 1.09 \\
\hline & \multicolumn{3}{|c|}{$\mathrm{LSD}=0.23$} & $\mathrm{LSD}=0.13$ \\
\hline Average & $1.40^{\mathrm{a}}$ & $\begin{array}{l}1.14^{\mathrm{b}} \\
\mathrm{D}=0 .\end{array}$ & & \\
\hline
\end{tabular}

Sümer et al. (2004), the unit that provides 540 and 540E speeds, transfers the engine speed to the PTO with two different transmission rates. In this way, the higher transmission ratio in the $540 \mathrm{E}$ application and the PTO speed, which is standard at a lower engine speed, can be provided as $540 \mathrm{~min}^{-1}$. Similarly, Atal (2006) stated that, depending on the loads, the $540 \mathrm{E}$ application had $30 \%$ lower fuel consumption values compared to the 540 application, the difference was due to working at a lower engine speed in the 540E application. Sümer et al. (2010b) in their study, they concluded that there are advantages in terms of fuel consumption in different loads with the $540 \mathrm{E}$ PTO application. Özgür (2009) stated that, there were significant increases in hourly fuel consumption and similar rates of decrease in specific fuel consumption due to tractor PTO load increase.

The graph of the field fuel consumption is given in Figure 3. According to the results of the variance analysis applied to the field fuel consumption values, the effect of the change in the PTO speed and feed rate on the field energy consumption was found significant $(\mathrm{P}<0.05)$ and the LSD test results are given in Table 4.

When Figure 3 and Table 4 are examined, the highest field fuel consumption was achieved as $64.51 \mathrm{ha}^{-1}$ at $\mathrm{V}_{1}$ working speed at 540 PTO application, while the lowest field fuel consumption was achieved as $36.81 \mathrm{ha}^{-1}$ at the $\mathrm{V}_{3}$ working speed and 540E PTO application.

The graph of the fuel consumption values per unit product is given in Figure 4. When the fuel consumption per unit product is evaluated in terms of consumption, the impact of the change in PTO applications and progress rate on the product energy consumption was found significant $(\mathrm{P}<0.05)$ and LSD test results are given in Table 5.

When Figure 4 and Table 5 are examined, it is seen that the product fuel consumption varies between $0.82-1.441$ $\mathrm{t}^{-1}$. While the lowest field-product fuel consumption value depending on the working speed of the machine was determined at the speed of $V_{3}$, this rate was followed by the speeds of $V_{2}$ and $V_{1}$ respectively. It is seen that the smallest field-product fuel consumption value related to PTO application is in $540 \mathrm{E}$ application. In the $540 \mathrm{E}$ application, it was observed that the average field-product fuel consumption decreased by $10 \%$ compared to 540 . Fieldproduct fuel consumption varies inversely with the working speed. An increase of $100 \%$ in the working speed reduced the average field-product fuel consumption by about 34\%. Bilgen and Sungur (1992) stated that by increasing the working speed in silage machines, field energy consumption decreased. Field fuel consumption decreased inversely with field and product business successes (Kafadar, 1997).

When the results are evaluated in general, it is concluded that it is more advantageous to use $540 \mathrm{E}$ application in the operation of machines that do not require large PTO power requirement. Similarly, Çiftçi and Çalışır (2018) emphasized that the $540 \mathrm{E}$ application is more advantageous in terms of fuel consumption compared to the 540 application for many tools and machines powered by PTO, and suggested that the 540E PTO application be used instead of 540 when the capacity is sufficient.

The results can be summarized as follows;

- PTO power consumption for all working combinations was determined to range between $9.90-8.87 \mathrm{~kW}$. PTO power consumption is increasing in direct proportion with the increase in the working speed of the machine.

- Hourly fuel consumption was determined to vary between $5.42-8.581 \mathrm{~h}^{-1}$. In the 540E PTO application, it was observed that the average hourly fuel consumption decreased by $11.9 \%$ compared to the 540 application. An increase of $100 \%$ in the working speed increased the average fuel consumption by $37.47 \%$. 
- It was determined that the field fuel consumption varies between $36.8-64.51 \mathrm{ha}^{-1}$ and the product fuel consumption varies between $0.82-1.44 \mathrm{l} \mathrm{t}^{-1}$. In $540 \mathrm{E}$ PTO application, it was determined that the average field-product fuel consumption has decreased by $10 \%$ compared to 540. An increase of $100 \%$ in the working speed reduced the average field-product fuel consumption by about $34 \%$.

- It was determined that 540E PTO application can be used successfully in the use of disk type silage machines, and thus, less energy per unit work can be consumed and input costs can be reduced.

\section{References}

Anonymous, 2008. Tarım ve Köy İşleri Bakanlığı Yayınları, Traktör Tekniği Kitabı (http://www.tarim.gov.tr/ sanal_kutuphane/basili/permem/kitapweb/tarmekkit/bilgi/b2 10.pdf).

Anonymous, 1991. Minitab Refence Manuel (release 14.1). Minitab Inc. State Universty Michigan.

Arın S. 1982, Bazı Tarım İşletmelerinde Kaba Yem Bitkileri Tarımı Mekanizasyonu Üzerinde Araşrırmalar, A.Ü:Ziraat fakültesi Tarım makinaları Bölümü, Ankara.

Atal M. 2006, Traktörlerde Güç ve Yakıt Tüketimi İçin Ölçüm Sisteminin Geliştirilmesi, Yüksek Lisans Tezi, Çukurova Üniversitesi Fen Bilimleri Enstitüsü, Adana.

Bilgen H, Sungur N. 1992, Ege Bölgesi Koşullarında Yerli Yapım Silajlık Mısır Hasat Makinası Üzerinde Bir Araştırma, OMÜ Ziraat Fakültesi Tarım Makinaları Bölümü, Tarımsal Mekanizasyon, 14, 14-16.

Bilgen H, Sungur N, Akdeniz C. 1992, Ege Bölgesinde (İzmir, Manisa ve Aydın) Silaj Yapım Tekniklerinin Saptanması Üzerine Bir Araştırma, Tarımsal Mekanizasyon 14, Ulusal Kongresi, Samsun, 306-316.
Düzgüneş O, Kesici T, Kavuncu O, Gürbüz F. 1987. Araştırma Deneme Metotları (İstatistik Metotları II). Ank. Üniv. Ziraat Fakültesi Yayınları, Yayın No: 1021, Ders Kitabı, 295, Ankara.

Evrenosoğlu M. 2006, Silajlık misır hasat mekanizasyonu sistemlerinin işletmecilik yönünden irdelenmesi, Ege Üniversitesi.

Çiftçi O, Çalışır S. 2018, The Impact of a Centrifuge Pump in the Fuel Consumption of Agricultural Tractors with Different Nominal Capacities Driven with 540 and 540E PTO Shafts, Selcuk Journal of Agriculture and Food Sciences, 32(2): 197205.

Güner M. 1998, Silaj Makinaları ve Yapısal Özellikleri, Tarımsal Mekanizasyon 18. Ulusal Kongresi, Tekirdağ.

Kafadar A. 1997. Bala Tarım İşletmesimde Silaj Mekanizasyonunun Optimizasyonu Üzerinde Bir Araştırma, Doktora Tezi. A.Ü. Ziraat Fakültesi Tarım Makinaları Bölümü, Ankara.

Özgür Z. 2009. Tarım Traktörlerinde Yüklenmelerin Bazı Motor Parametreleri Üzerindeki Etkilerinin Belirlenmesi, Yüksek Lisans Tezi, Onsekiz Mart Üniversitesi Fen Bilimleri Enstitüsü, Çanakkale

Saral A, Avcıoğlu OA. 2002. Motorlar ve Traktörler. Ankara Üniversitesi Tarım Makinaları Bölümü Ders kitabı: 482. Yayın no:1529. Ankara.

Sümer SK, Has M, Sabancı A. 2004. Türkiye'de Üretilen Tarım Traktörlerine Ait Teknik Özellikler. Ç.Ü. Ziraat Fakültesi Dergisi. 19(1): 17-26. Adana.

Sümer SK, Kocabıyık H, Say SM, Çiçek G. 2010a, Traktörlerde 540 ve 540 E Kuyruk Mili Çalışma Karakteristiklerinin Tarla Koşullarında Kıyaslanması, Tarım Bilimleri Dergisi Journal of Agricultural Sciences, 16(4): 37-45

Sümer SK, Kocabıyık H, Say SM, Çiçek G. 2010b. Comparisons of 540 And 540E PTO Operations in Tractors Through Laboratory Tests, Bulgarian Journal of Agricultural Science, 16(4): 526-533 